\title{
COMPETITION, CONTESTABILITY AND MARKET STRUCTURE FOR SECURITIES FIRMS IN TAIWAN
}

\author{
Chang-Sheng Liao' $\quad$ 'College of Management, Samming University, Fujian, China, Department of \\ Finance and Cooperative Management, National Taipei University, \\ Taiwan, Republic of China \\ Email:sheng2009tw@gmail.com Tel:+886-2-2502-46.54
}

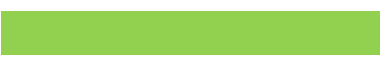

Article History Received: 28 December 2017 Revised: 19 March 2018 Accepted: 23 March 2018 Published: 28 March 2018

\section{Keywords}

Securities firms

Market structure

Contestability

X-Efficiency

Structure-conduct-performance

Hypothesis

Efficient structure hypothesis.

JEL Classification:

G22, L13, L25, L44.

\begin{abstract}
The purpose of this study is to investigate securities firms' market structure and contestability in Taiwan over the period from 1998 to 2006. This is the first study to integrate structural and non-structural approaches to the evaluation of competitive conditions in securities firms. The findings of this study have managerial implications, as the results show that market share is positively related to profitability but negatively related to efficiency, implying that the pursuit of market share may not be an appropriate strategy for securities firms. Empirical results show that securities firms are not in perfect competition and that the market is instead characterised by monopolist competition. The results regarding changes in the degree of competition show that securities firms' competitive condition is not improving. The government is to advance a serial of financial reform policies, but they do not affect securities firms, so the market remains a monopolist competitive environment with a lower level of contestability.
\end{abstract}

Contribution/ Originality: This is the first study to integrate structural and non-structural approaches to evaluate competitive conditions in securities firms in Taiwan. The findings of this study that results of structural and non-structural approaches are compatible.

\section{INTRODUCTION}

The traditional literature on the measurement of competition may be divided into two streams called the structural and non-structural approaches. The structural approach to model competition mainly includes the structure-conduct-performance hypothesis (SCP) and the efficient structure hypothesis (ES). Most previous studies that have used a structural approach to analyse the banking industry have covered both developing and developed countries, such as the US (Berger, 1995; Berger and Hannan, 1998) European countries (Goldberg and Rai, 1996) Taiwan (Yu, 2003) Korea (Park and Weber, 2006) and Bangladesh (Samad, 2008). On the other hand, non-structural approaches to competitive behaviour have also been developed, namely the Iwata model, the Bresnahan model, and the Panzer and Rosse model. These models use concepts from the new empirical industrial organisation school; Bikker and Haaf (2002) have stated that these approaches measure competition and emphasise the analysis of the competitive conduct of banks without using explicit information about the structure of the market. Previous studies have used the Panzar and Rosse model to measure the degree of competition in the banking industry, such 
as in Japan (Molyneux et al., 1996) Britain (Matthews et al., 2007) China (Yuan, 2006) Austria (Hahn, 2008) and Italy (Coccorese, 2009). In sum, we know that both the structural and the non-structural approach are useful tools for measuring competitive conditions. However, few studies have applied these models to measuring competitive conditions in other financial institutions. The banking, insurance, and securities industries constitute the main pillars of a country's financial market. Securities firms therefore form the bridge between different customers, providing investment targets in enterprises for both institutional and non-institutional investors. It is helpful to investigate the securities firms' degree of competition. Tsutsui and Kamesaka (2005) applied the Panzar and Rosse model to evaluate the competitive conditions in Japanese securities firms. On the other hand, most previous studies have only used a single approach to evaluate competitive conditions in the banking industry, though Hahn (2008) used structural and non-structural approaches to measure competitive conditions in the banking industry in Austria. On this basis, we try to integrate structural and non-structural approaches to evaluating competitive conditions in securities firms. The purpose of this study is to investigate the securities firms' market structure and contestability in Taiwan. We conducted a panel econometric analysis that allowed us to test the hypotheses that have become the most prominent in the literature on financial institutions' profitability. In addition, we tested whether securities firms were, on average, contestable over the period from 1998 to 2006. This study used the Panzar-Rosse H-statistic to estimate the degree of competition. The remainder of this paper is organised as follows. Section 2 is a review of securities firms' development process. Section 3 describes the empirical equation model, which will evaluate the market structure hypotheses and the degree of competition, and defines the study variables. Section 4 analyses the results of the testing done to evaluate the market structure hypotheses and to measure the degree of competition in securities firms. Finally, conclusions are drawn, empirical results presented, and suggestions provided.

\section{BACKGROUND}

The Taiwanese securities market plays a very important role in emerging markets; in the past, Taiwan, Korea, Hong Kong, and Singapore were called the "four Asian tigers". They have had a more rapid and surprising economic growth rate than the rest of the world, and the stock market has grown very quickly. The Taiwanese securities market is among the top 10 largest securities markets in the world, and the stock turnover ratio is $153.28 \%$, higher than in the Tokyo and Hong Kong securities markets; indeed, of the Asian securities markets in 2007, it was only lower than Korea's. This indicates that Taiwan securities market is very active. In particular, the Taiwanese securities market has a higher dividend yield ratio than do those of other Asian countries, so it may attract more foreign investors. Most international investment institutions attach a high degree of importance to the Taiwanese market. For instance, in Taiwan, foreign direct investment has increased significantly, and the accumulated net inward remittance grew from NT\$11.03 billion in 1998 to NT\$1246.89 billion in 2008; moreover, the percentage of market value held by foreign investors was $28.98 \%$ in 2008 , although the highest percentage of market value by foreign investors was 31.9 in 2006. The ratio of market value to GDP was $170.37 \%$ in 2007, showing that securities trading are an important commercial activity for the Taiwanese economy. ${ }^{1}$

The Taiwanese financial market underwent significant structural changes beginning at the end of the 1980 , and the government allowed entry into individual financial markets for new financial institutions. The government eased the restrictions on the establishment of securities brokerage firms and permitted the establishment of securities firms in 1988. In addition, the government allowed foreign securities firms to establish branches in Taiwan in 1990. The number of securities firms increased from 28 in 1987 to 373 in 1990, accompanied by the first bull market in securities' developing history. However, the number of securities firms has significantly decreased due to recessions, global financial market changes and other events. These events include the shock of the Asian financial crisis in 1997, domestic enterprises' financial distress in 1998, and the first alternation of the ruling party

${ }^{1}$ Data source: Financial supervisory commission, Executive Yuan, Securities and Futures Bureau. http://www.sfb.gov.tw. 
in 2000. Thus, some firms that had displayed poor performance went out of business or underwent mergers. As a result, in 2007, the number of securities firms in Taiwan was only 97. Since 2001, the government's adoption of a series of financial reform policies to improve the assets quality of financial institutions and encourage mergers among financial institutions. Due to the smaller firms' lack of reliable banking support and cross-selling platforms, there has been a wave of mergers in securities firms. In sum, the securities industry has undergone significant changes in terms of its market structure, regulation policies, and types of business since deregulation.

\section{SPECIFICATION OF THE MODELS}

\subsection{Testing for Market Structure Hypotheses}

In this section, we briefly introduce the hypotheses related to market structure. In the past, two competing hypotheses sought to examine the relationship between structure and performance in financial institutions. The traditional structure-conduct-performance paradigm hypothesises that where market resources are highly concentrated, collusion among banks will result in monopoly rents. The SCP asserts that this finding reflects the setting of prices that are less favourable to consumers (lower deposit rates, higher loan rates) in these markets, while a related theory is the relative market power hypothesis (RMP), which asserts that only firms with large market shares and well-differentiated products are able to exercise market power in pricing these products and earn supernormal profits (Berger, 1995). On the other hand, the SCP hypothesis has been challenged and developed further based on an alternative view, the efficient-structure paradigm hypothesis (ES), which suggests that efficient firms increase in size and market share because of their ability to generate higher profits, which often leads to higher market concentrations. Under the X-efficiency version of the efficient-structure hypothesis (ESX), firms with superior management or production technologies have lower costs and therefore have higher profits. Under the scale-efficiency version of the efficient structure hypothesis (ESS), firms with similar technology and comparably skilled management may operate at different levels of scale efficiency (Berger, 1995). Goldberg and Rai (1996) explain that the positive relationship between profits and concentration is explained by lower costs achieved through either superior management or superior production processes.

As outlined above, the reduced form profit equation is used to test the market structure hypotheses, using an empirical equation such as

$$
R O A_{i t}=\alpha_{0}+\alpha_{1} X E F F_{i t}+\alpha_{2} S E F F_{i t}+\alpha_{3} M S_{i t}+\alpha_{4} C O N C_{t}+\sum_{q=1}^{2} \alpha_{q} Z_{i j t}+\varepsilon_{i t}
$$

where ROA denotes the return on assets and is a proxy for the profitability of individual securities firms, the XEFF reflects the securities firm's efficiency, SEFF indicates scale efficiency, MS indicates market share, CONC indicates the market concentration, the $Z$ vectors represent control variables, including SIZE (indicates the securities firm's assets), SPEC (indicates the securities firm's degree of product specialisation), the $\varepsilon$ are random errors, the time periods are $t=1,2 \ldots . T$, and the securities firms are $i=1,2, \ldots, N$. Within Equation (1), which tests which market structure hypotheses are supported, the independent variable ROA acts as a proxy for the profitability of individual securities firms. If the ES hypothesis is supported, XEFF and SEFF should be statistically significant, while the other variables are insignificant. MS indicates the market share; if the RMP hypothesis is supported, the sign is significantly positive and is positively related to profitability. CONC indicates the market concentration under the SCP hypothesis. CONC is expected to be significantly positive, and the other one is simply irrelevant, while efficiency variables are appropriate exogenous variables but are viewed as relatively unimportant. Other control variables include SIZE, which indicates the securities firm's assets, and SPEC, which indicates the securities firm's degree of product specialisation. Like previous studies, the reduced form (1) allows all four hypotheses to be valid simultaneously, e.g., Berger (1995); Choi and Weiss (2005); Park and Weber (2006); Hahn (2008). 


\subsection{Estimating Securities Firms X-Efficiency}

Following Berger (1995) the securities firms efficiency measured by distribution free approach. Using the translog function to estimate the cost efficiency of securities firms by Christensen et al. (1973) we inferred the translog function, on which the securities firms cost function can be based and written as:

$$
\begin{gathered}
\ln T C=\alpha_{0}+\sum_{i=1}^{3} \alpha_{i} Q_{i}+\sum_{j=1}^{2} \beta_{j} P_{j}+\frac{1}{2} \sum_{i=1}^{3} \sum_{j=1}^{3} \alpha_{i j} \ln Q_{i} \ln Q_{j}+\frac{1}{2} \sum_{j=1}^{2} \sum_{k=1}^{2} \beta_{j k} \ln P_{j} \ln P_{k} \\
+\sum_{i=1}^{3} \sum_{j=1}^{2} \rho_{i j} \ln Q_{i} \ln P_{j}+\varepsilon_{i t}
\end{gathered}
$$

where TC is the total operating cost, $Q_{i}$ is the ith securities firms' output, $P_{j}$ is the jth input price, $\varepsilon_{i t}$ is the error term, and $\varepsilon_{i t} \square^{i i d} \mathrm{~N}\left(0, \sigma_{i t}^{2}\right)$. The usual symmetry restrictions are imposed, i.e. $Q_{i j}=Q_{j i}, P_{j k}=P_{k j}$.

Few studies used the efficiency of securities firms to define the firms' output-input specification. In securities firms' cost equation, we follow the input-output variables adopted by previous studies, ${ }^{2}$ and refer mainly to the source of securities revenue items. Thus, we use output items including revenue from brokerage income, underwriting income, and interest income; input items such as salary expenses, and capital expenses are measured by operating expenses to reduce salary expenses.

This method has been used to disentangle the composite error term using a free distribution assumption. The cost equation is specified as:

$$
\ln T C_{i t}=\ln C_{t}\left(Q_{i t}, P_{j t}\right)+\ln x_{i}+\ln v_{i t}
$$

where $\ln T C_{i t}$ is the total operating cost, $C(Q, P)$ is a cost function with output quantity and input price vector, and the error term is $\varphi_{i}=x_{i}+v_{i}$ and decomposes into two parts, of which $v_{i t}$ is the conventional white noise and a mean-zero random error, while $x_{i t}$ is a multiplicative $\mathrm{X}$-inefficiency factor. Inefficiency $\ln \hat{x}_{i}$ is estimated econometrically, and the residual is calculated as $\ln \hat{x}_{t}^{\min }-\ln \hat{x}_{i t}$. The function $\ln \hat{x}_{i}$ is transformed into a normalised X-Efficiency measure as follows:

$$
\mathrm{x} E F F_{i t}=\exp \left(\ln \hat{x}_{t}^{\min }-\ln \hat{x}_{i t}\right)
$$

where $\ln \hat{x}_{t}^{\text {min }}$ indicates the minimum in all firms and $\ln \hat{x}_{i t}$ for all $i$ for that $t$. while It may be seen that this is an estimate of $\hat{x}^{\mathrm{min}} / \hat{x}_{i}$. Suppose that the XEFF value equals one; this would indicate that the firm is the most efficient and ranges over $(0 \sim 1)$.

Scale efficiency is measured based on the cost function in (2) as well. For each firm's output mix and input prices, a U-shaped multiproduct average cost curve was traced out, and the scale-efficient output vector $Q^{s e}$ at the

\footnotetext{
${ }^{2}$ Few previous studies have investigated the topic of the efficiency of securities firms e.g., Fukuyama and Weber (1999); Wang, Tseng and Weng (2003); Zhang, Zhang and Luo (2006).
} 
bottom of the $\mathrm{U}$ was determined. The scale efficiency was determined as the ratio of predicted cost of $Q^{s e}$ to the predicted cost of the bank's actual output Q, multiplied by the ratio of outputs to correct for absolute size differences:

$$
\mathrm{SEFF}=\exp \left[\ln \hat{C}\left(Q^{s e}, P\right)-\ln \hat{C}(Q, P)\right] \times\left[\left(\sum_{J=1}^{3} Q_{j}\right) /\left(\sum_{k=1}^{3} Q_{k}^{s e}\right)\right]
$$

where the $\ln \hat{C}$ s are predicted cost values. As with any scale efficiency measure, it ranges over $(0,1)$. It may be seen that this is an estimate of $A \hat{C}^{s e} / A \hat{C}_{i}$, the ratio of minimum predicted average costs to actual predicted average costs for the securities output mix.

\subsection{Testing for Contestability Hypothesis}

Market power is then identified using an index (the Panzar-Rosse H statistic), measured as the sum of the elasticity of the reduced-form revenue with respect to the entire factor price (Panzar and Rosse, 1987). Panzar and Rosse focus on the measure of the input elasticities of total revenues $(\mathrm{R})$ of the individual firm with respect to the firm's input prices $\left(w_{j}\right)$, which are summed up to an amount consistent with the so-called "H-statistic". The Hstatistic can be written as below:

$$
H=\sum_{j=1}^{m}\left(\frac{\partial R^{*}}{\partial w_{j}} \frac{w_{j}}{R^{*}}\right)
$$

They demonstrate that $\mathrm{H} \leq \mathrm{O}$ in the case of a monopoly, that $\mathrm{H} \leq 1$ in the case of monopolistic competition (Chamberlinian equilibrium), in which marginal revenue equals marginal cost and profit is zero, and that $\mathrm{H}=1$ in the case of perfect competition. Panzar and Rosse denote the revenue function as $\mathrm{R}=\mathrm{R}(\mathrm{y}, \mathrm{z})$, where $\mathrm{y}$ is the output and $\mathrm{z}$ stands for exogenous variables that affect revenue. The cost function is assumed to be $\mathrm{C}=\mathrm{C}(\mathrm{y}, \mathrm{p}, \mathrm{t})$, where $\mathrm{p}$ represents input prices and $t$ stands for other exogenous variables. Since profits are defined as $\pi \equiv R(y, z)-C(y, p, t)$, profit-maximising $\mathrm{y}$ is written as $y^{*}=y(z, p, t)$. Substituting this into the revenue function, the reduced function can be written as $R^{*}=R(y(z, p, t), z) \equiv \tilde{R}(z, p, t)$. As a result, Panzar and Rosse H-statistics are calculated using estimates from this equation.

Tsutsui and Kamesaka (2005) state that the basic regression equation can be used to test for degree of contestability in securities firms; these empirical functions include a full translog function, a partial translog function and a Cobb-Douglas function. Our observations only number 162 in this study. While we used a full translog function to measure the degree of competition for securities firms, this may cause a bias problem with the degree of freedom. As a result, the partial translog function and a Cobb-Douglas function are considered. The partial translog function is as below:

$$
\begin{aligned}
\ln \operatorname{TRTA}_{i t}=b_{0} & +b_{1} \ln w_{i t}+b_{2} \ln k_{i t}+b_{3} \ln r_{i t}+b_{4} B R O K E_{i t}+b_{5} U W R I T_{i t}+b_{6} D E A L_{i t} \\
& +b_{7}\left(\ln w_{i t}\right)^{2}+b_{8}\left(\ln k_{i t}\right)^{2}+b_{9}\left(\ln r_{i t}\right)^{2}+u_{i t}
\end{aligned}
$$


The Cobb-Douglas function is as below:

$$
\begin{aligned}
\ln T_{R T A_{i t}=} & b_{0}+b_{1} \ln w_{i t}+b_{2} \ln k_{i t}+b_{3} \ln r_{i t}+b_{4} \text { BROKE }_{i t}+b_{5} U W R I T_{i t} \\
& +b_{6} \text { DEAL }_{i t}+u_{i t}
\end{aligned}
$$

The H-statistic is defined as $\mathrm{H} \equiv b_{1}+b_{2}+b_{3}$,

where TRTA indicates the total revenue divide by total asset, $w$ indicates the wage rate, $k$ indicates the price of capital equipment, and $r$ indicates the cost of funding. For the exogenous variables in the revenue function, following Tsutsui and Kamesaka (2005) we define the shares of three types of businesses, BROKE, UWRIT and DEAL, where BROKE, UWRIT and DEAL indicate the brokerage fee, underwriting fee, and the income (loss) from equity dealing business, respectively. Another primary purpose of this study is to test the degree of competition in securities firms. We specify the variables in the revenue equation. w indicates the wage rate and is measured by salary expenses divided by the number of employees, and $k$ indicates the capital equipment cost. Capital expenses are measured by operating expenses to reduce salary expenses; the cost is measured by dividing capital expenses by fixed assets. $r$ indicates the cost of funding; the price is measured by dividing interest expense by total assets. ${ }^{3}$ For the exogenous variables in the revenue function, following Tsutsui and Kamesaka (2005) we define the shares of three types of business: BROKE, UWRIT and DEAL, where BROKE is measured by dividing brokerage fees by total assets. Securities firms mainly generate their revenue from brokerage fees, so we expect the sign to be strongly positive. UWRIT is measured by dividing underwriting fees by total assets. Underwriting activity is significantly related to the IPO market; we are also able to observe IPO market transactions. DEAL is measured by the income (loss) from firms' equity dealing business. This business reflects whether securities firms' traders profit from the stock market. The primary data source for this study was the Taiwan Economics Journal (TEJ); the samples included 18 listed securities firms during the period from 1998 to 2006. All variables are measured in millions of NT dollars, expressed in real terms and deflated by the consumer price index (CPI) indexed to 2006 $(2006=100)$. Descriptive statistics of the empirical variables are provided in Table 1.

Table-1. Summary Statistics

\begin{tabular}{l|l|l}
\hline & Mean & Std. \\
\hline (a) Market structure & & \\
\hline SIZE & 17.1847 & 1.5067 \\
\hline ROA (\%) & 4.554 & 4.129 \\
\hline XEFF & 0.1751 & 0.03 \\
\hline SEFF & 0.6875 & 0.1506 \\
\hline MS $\%)$ & 3.76 & 9.5 \\
\hline CONC $(\%)$ & 3.2901 & 1.2258 \\
\hline SPEC & 0.5145 & 0.0025 \\
\hline (a)Contestability test & & \\
\hline Revenue/ Asset, TRTA & 0.1329 & 0.0395 \\
\hline Price of labor (w) & 841.659 & 167.5655 \\
\hline Price of capital (k) & 0.6264 & 0.0967 \\
\hline Price of fund $(\mathrm{r})$ & 0.0157 & 0.0077 \\
\hline BROKE $(\%)$ & 5.11 & 0.59 \\
\hline UWRIT $(\%)$ & 0.022 & 0.04 \\
\hline DEAL $(\%)$ & 0.67 & 0.204 \\
\hline Source: the primary data source for this study was the Taiwan Economics Journal (TEJ). The input-output variables unit measure by millions, fund
\end{tabular}

Source: the primary data source for this study was the Taiwan Economics Journal (TEJ). The input-output variables unit measure by millions, fun and Capital price measure by percent.


function is a convention to avoid possible multi-colinearity. 


\section{EMPIRICAL RESULTS}

\subsection{Results of Testing for Market Structure Hypotheses}

In this section, the empirical analysis focuses on the estimates of Equation (1). We would like to explain the relationship between structure and performance in securities. We estimate Equation (1) using pooling OLS, a fixedeffect model and a random-effect model. ${ }^{4}$ As can be seen in Table 2 , the coefficient of X-EFF is insignificant, but the coefficient of S-EFF is positive and significant, implying that a more efficient firm profit does not always perform better than less efficient firms. However, we do find that scale efficiency is a key exogenous variable; the firms may have lower unit costs and higher unit profits simply because they operate at an optimal scale. Thus, the results show that the scale efficiency version of the ES hypothesis is supported, but they do not support the X-efficiency version of the ES hypothesis.

The coefficient of MS is significantly positive, but the CONC is negative and insignificant. Similarly, for the market structure hypothesis, the result does not support the SCP hypothesis due to the lack of a relationship between concentration and profit. The positive relation between market share and profit show that the RMP hypothesis is supported. Berger (1995) states that, if only RMP holds, CONC has a zero coefficient because CONC is only spuriously related to profit through its correlation with MS and that the coefficient of all the other key variables are either relatively small or zero. Overall, the results show that RMP and ESS hypotheses are supported, but, compared with each coefficient in regression (1), this suggests that RMP rather than the ESS hypothesis has strong supporting evidence.

The control variables' results show that the coefficient of SIZE is significantly negative and that the coefficient of SPEC is negative but insignificant. This implies that securities firms seeking to increase level of specialization do not enjoy high profit. Fitch Rating report indicates that the overall earnings quality of the sector will remain poor due to product diversity and volatile trading results. Thus, securities firms concentrate primarily on improving efficiency through diversification and increased economies of scope. The relationship between size and profit is negative, implying that size does not increase a firm's profit. Since 2001, the Taiwanese financial institution has seen a wave of merger activity; this wave is a possible cause of the inverse effects of increased asset size, which has caused firm size to deviate from the best-practice frontier.

Table-2. Results of the regression of market structure

\begin{tabular}{l|l|l|l}
\hline & Dependent variable=ROA & FM & RM \\
\hline & OLS & 0.0126 & 0.0082 \\
XEFF & 0.0024 & $(1.0208)$ & $(0.7915)$ \\
& $(0.2861)$ & 0.0255 & 0.0186 \\
SEFF & 0.0098 & $(2.1941)^{* *}$ & $(1.7083)^{*}$ \\
\hline MS & $(0.9021)$ & 0.8546 & 1.4915 \\
& 1.6785 & $(1.8348)^{*}$ & $(3.8273)^{* * *}$ \\
\hline CONC & $(4.108)^{* * *}$ & -4.3056 & -7.7707 \\
& -7.886 & $(-1.3897)$ & $(-2.9354)^{* * *}$ \\
\hline SIZE & $(-2.8752)^{* * *}$ & -0.0324 & -0.0252 \\
& -0.027 & $(-4.6855)^{* * *}$ & $(-4.2095)^{* * *}$ \\
\hline SPEC & $(-4.2699)^{* * * *}$ & -0.0079 & -0.0435 \\
& -0.1326 & $(-0.2215)$ & $(-1.361)$ \\
\hline \multirow{2}{*}{$R^{2}$} & $(-4.5298)^{* * *}$ & 0.5445 & 0.2001 \\
\hline
\end{tabular}

Notes: XEFF reflects the securities firms' efficiency, SEFF indicates the scale of economics, MS indicates the market share, CONC indicates the market concentration, the $Z$ vectors represent control variables, include SIZE indicates the securities firm's assets; SPEC indicates the securities firm's degree of product specialization. ${ }^{*} \alpha=0.1$ significant at the $10 \%$ level, $* * \alpha=0.05$ significant at the $5 \%$ level, $* * * \alpha=0.01$ significant at the $1 \%$ level.

${ }_{4}^{4}$ The F test, LM test, and Hausman test indicated that the fixed effect model is more appropriate for Panel A. We also listed the OLS, and the random effect model provides a reference. 


\subsection{Additional Testing for Market Structure Hypotheses}

In this section, we test for support for the quiet life effect in securities firms in Taiwan. Berger and Hannan (1993) refer to these conditions as testing the "quiet life" hypothesis posed by Hicks (1935). This hypothesis states that as firms enjoy greater market power and concentration, inefficiency follows not because of non-competitive pricing but rather because of a relaxed environment that produces no incentives to minimise costs. Assuming the market share and concentration as proxy for firms' market power index, the market power may result in reduced operating efficiency and higher costs, so the relationship between efficiency and market share and concentrations should thus be negative if the quiet life hypothesis conclusions are to be supported. ${ }^{5}$

Table 3 reports the results for Eqs. (9) and (10), testing the Hicks' "quiet life" hypothesis. The results do not generally support the quiet life hypothesis, as the coefficient is not consistently negative, and the results suggest that the market power hypothesis is not supported either. The results are consistent with Goldberg and Rai (1996) estimated results for the banking industry.

These findings indicate that market share and concentration do not play an important role in securities firms' efficiency. In Taiwan, securities firms share the view that greater market share would follow higher profitability. Previous studies have found that market share is positively related to profitability in financial service industries, e.g. Chu et al. (2008) the empirical results for further securities firms firmly show that the pursuit of greater market share can generate profitability. Similar to the prior section's empirical results, securities firms would now willingly sacrifice something to expand their market share, such as not enforcing minimum cost targets and wasting resources to raise an already unrealistic market share target. These operating strategies would lead efficiency to decrease but might not reduce firms' profitability. ${ }^{6}$ This result of control variables is consistent with former results, implying that this study finds should be robust.

Table-3. Results of regression of additional test

\begin{tabular}{|c|c|c|c|c|c|c|}
\hline & \multicolumn{3}{|l|}{ Panel A } & \multicolumn{3}{|l|}{ Panel B } \\
\hline & OLS & FM & RM & OLS & FM & RM \\
\hline MS & $\begin{array}{l}-1.988 \\
(-0.436)\end{array}$ & $\begin{array}{l}4.1585 \\
(3.42)^{* * * *}\end{array}$ & \begin{tabular}{|l|}
3.1004 \\
$(0.9507)$
\end{tabular} & $\begin{array}{l}-1.1567 \\
(-0.3615)\end{array}$ & $\begin{array}{l}-1.9374 \\
(-0.5469)\end{array}$ & $\begin{array}{l}-2.3492 \\
(-0.7318)\end{array}$ \\
\hline $\mathrm{CONC}$ & $\begin{array}{l}1.277 \\
(0.469)\end{array}$ & $\begin{array}{l}-40.9037 \\
(-1.8332)^{*}\end{array}$ & $\begin{array}{l}-34.2926 \\
(-1.6041)\end{array}$ & $\begin{array}{l}23.1516 \\
(1.1093)\end{array}$ & $\begin{array}{l}27.7448 \\
(1.2005)\end{array}$ & $\begin{array}{l}31.0464 \\
(1.4718)\end{array}$ \\
\hline$\overline{\mathrm{SIZE}}$ & $\begin{array}{l}0.289 \\
(3.159)^{* * * *}\end{array}$ & $\begin{array}{l}0.2213 \\
(0.0544)\end{array}$ & $\begin{array}{l}0.2086 \\
(4.144) * * *\end{array}$ & $\begin{array}{l}-0.017 \\
(-0.3535)\end{array}$ & $\begin{array}{l}0.1039 \\
(0.1846) \\
\end{array}$ & $\begin{array}{l}-0.0202 \\
(-0.4177) \\
\end{array}$ \\
\hline$\overline{\mathrm{SPEC}}$ & $\begin{array}{l}.0949 \\
(-0.9653) \\
\end{array}$ & $\begin{array}{l}0.2591 \\
(0.2515) \\
\end{array}$ & \begin{tabular}{|l|}
0.2053 \\
$(0.837)$ \\
\end{tabular} & $\begin{array}{l}-0.3035 \\
(-1.3224) \\
\end{array}$ & $\begin{array}{l}-0.8693 \\
(-3.3381)^{* * * *}\end{array}$ & $\begin{array}{l}-0.7233 \\
(-2.9844))^{* * *} *\end{array}$ \\
\hline $\mathrm{ROA}$ & $\begin{array}{l}-3.0321 \\
(0.122) \\
\end{array}$ & $\begin{array}{l}0.6953 \\
(0.6628)\end{array}$ & $\begin{array}{l}0.5853 \\
(0.92)\end{array}$ & $\begin{array}{l}0.5169 \\
(0.8667)\end{array}$ & $\begin{array}{l}1.0914 \\
(1.5905)\end{array}$ & $\begin{array}{l}0.702 \\
(1.123)\end{array}$ \\
\hline$R^{2}$ & 0.2885 & 0.7739 & 0.8161 & 0.0544 & 0.4502 & 0.4784 \\
\hline
\end{tabular}

Notes: All independent variables definition see Table 2, the Panel A dependent variable is XEFF, and the Panel B dependent variable is SEFF, ROA indicates the return of asset. The F test, LM test, and Hausman test indicated that the random effect model is more appropriate for Panel $\mathrm{B}$ and $\mathrm{C}$ both. ${ }^{*} \alpha=0.1$ significant at the $10 \%$ level, ${ }^{* *} \alpha=0.05$ significant at the $5 \%$ level, ${ }^{*} * * \alpha=0.01$ significant at the $1 \%$ level.

The findings of this study have a particular managerial implication, that market share plays an important role for securities firms' profitability in Taiwan; Liao (2010) argues that firms reduce efficiency in order to gain market share. Securities firms would now willingly sacrifice efficiency to expand their market shares since they believe that they will receive great benefit in the future from having a large market share. Our results provide direct evidence for the latter viewpoint that market share is positively related to profitability, but insignificant positively related to

\footnotetext{
${ }^{5}$ Following Goldberg and Rai (1996) testing whether quiet life hypothesis is supported, for brevity, we not listed the empirical regression, but available upon request to the authors.

${ }^{6}$ We must note that "profit" is an accounting concept, but "efficiency" is a concept based in economics. We use a complex and advanced methodology to estimate it. This discussion is outside the range of our study, so we do not explain the difference between accounting and economics.
} 
efficiency (except with column 2). Is the pursuit of market share, then, an appropriate strategy for securities firms? This study cannot give a robust solution for this question, suggesting instead that securities firms strike a balance between profitability and efficiency. In general, a more profitable firm but not have greater efficiency, implying that their excessive rent as a result of market structure signals an imperfect market. Thus, we suggest that the government should be more concerned with improving efficiency rather than increasing profitability as a result of gaining market power.

\subsection{Results of Testing for Contestability Hypothesis}

The degree of market competition in financial institutions is always a matter of practical importance to policy makers and scholars. We thus use the Panzar-Rosse H-statistic to measure the degree of competition in securities firms. The estimated function involves a partial translog function and a Cobb-Douglas function to discover the appropriate functional function; a conventional F-test was applied to the two Equations (7) and (8). The result shows that the Cobb-Douglas function is rejected against the partial translog function in the pooling sample (the period from 1998 to $2006, \mathrm{~F}=3.4142$ ). As a result, we only report the results of the partial translog function in this study.

Shaffer (1982) state that if the sample is not in long-run equilibrium, it can negatively skew the Panzar-Rosse $\mathrm{H}$-statistic. To test this Hypothesis, he has proposed to estimate the value of $\mathrm{H}$ by using return on assets (ROA) as the dependent variable instead of revenues, the sum of elasticities of return on assets with respect to input prices will be zero for a sample in long run equilibrium, but not otherwise. Thus, to test that the observations are in longterm equilibrium, the testing equations as can be written below:

$$
\begin{gathered}
R O A_{i t}=b_{0}+b_{1} \ln w_{i t}+b_{2} \ln k_{i t}+b_{3} \ln r_{i t}+b_{4} B R O K E_{i t}+b_{5} U W R I T_{i t}+b_{6} D E A L_{i t} \\
+b_{7}\left(\ln w_{i t}\right)^{2}+b_{8}\left(\ln k_{i t}\right)^{2}+b_{9}\left(\ln r_{i t}\right)^{2}+u_{i t} \\
H_{R O A}=b_{1}+b_{2}+b_{3}
\end{gathered}
$$

From Table 4, the results shown do not reject null hypothesis $H_{R O A}=0$ in our study period; the sum of elasticities of ROA with respect to input price will be zero for a sample in the long-run equilibrium, so our estimated samples are in long-run equilibrium, except during 1999; as a result, the resulting estimate has a low value. Using OLS to estimate Eq. (7), Table 5 reports the yearly results and pooling sample for 1998 to 2006 . The coefficient of the price of wages is considerably larger than the other two input factors, even though it is a negative value; this may be because employee expenses usually represent the main part of firms' total costs. Securities firms' main business comes from brokerage fees in Taiwan. According to the Fitch Rating Ltd., which lists breakdowns of the securities firms' operating revenues, the brokerage business is the most prominent, representing 78.5 percent in 2006. The securities firms seeking to increase their brokerage business often adopt a higher bonus strategy to encourage sales agents to take on new clients, and the bonus amounts follow stock market fluctuations.

The coefficient of BROKE is significantly positive with all results, implying that the brokerage business earned relatively more revenue; this outcome is consistent with that found by Tsutsui and Kamesaka (2005). The coefficient of UWRIT is positive and significant, except with 2004, when the sign of UWRIT is negative but not significant. The underwriting business is decreasing, due to Taiwan's IPO market performing poorly from 2003 to 2006. The coefficient of DEAL is positive and significant in the pooling regression, but most signs of DEAL are insignificant. The sign is positive and significant in 2005 and 2006. These results show that profit from stock market was strong in this period. On the other hand, this reflects the fact that it is hard for securities firms' traders to obtain a stable profit from the stock market for each year. 
Regarding the yearly regressions, the partial null hypothesis results cannot accurately determine the market's status; consequently, the test has an ambiguous result. For instance, the H-statistic is -0.4498 in 1998, but neither $\mathrm{H}=\mathrm{O}$ nor $\mathrm{H}=1$ is rejected, so it is difficult to recognise which status is really the condition for securities in that year. Although Al-Muharrami et al. (2006) results show that the test result for $\mathrm{H}=0$ and $\mathrm{H}=1$ are both rejected for the banking industry in UAE $(\mathrm{H}=1.04)$, they view the competitive condition as perfect competition. Thus, it may be possible to view the markets in our test as in a state of monopoly. In addition, we cannot reject the $\mathrm{H}=1$ hypothesis in 2005; this implies that the market status in a perfect competition, but we suggest that the monopoly in a perfectly contestable market might be representative of the Taiwan securities firms market. ${ }^{7}$ The H-value is 0.4551 over the period of 1998-2006, and the hypotheses of $\mathrm{H}=\mathrm{O}$ and $\mathrm{H}=1$ were strongly rejected, the results suggesting that the securities firms' market is characterised by monopolistic competition. This is a not a surprising result; most previous studies, such as Shaffer (1982); Molyneux et al. (1994); De Bandt and Davis (2000); Bikker and Haaf (2002); and Matthews et al. (2007) have discovered that the banking market is in monopolistic competition. ${ }^{8}$

Hahn (2008) states that an H-value between 0.5 and 1 and suggests a fairly high level of contestability. We find the $\mathrm{H}$-value to be below 0.5 - this value is 0.4551 -implying that the securities firms are in a lower level of contestability. Securities firms in Taiwan believe that gaining market share naturally leads to greater profit; therefore, these firms like to pursue market share and concentration." Since 2001, the government has encouraged merger and acquisition activity of financial institutions. These policies aim to make larger, more competitive and international financial institutions, but there might be a decrease in the degree of market competition due the increase of individual firms' market power. This findings support the results in the former section, suggesting that market power may not play an important role for firms' efficiency, but has an important role in profitability. Under a lower degree of competition, firms have a higher profit despite not having efficiency because they are facing fewer competitive rivals within their market. Even through many changes and financial reforms for the securities firms market in Taiwan occurred during the period of analysis, competitive conditions did not change significantly over the period 1998-2006. The securities industry is still in a lower level of competition.

De Bandt and Davis (2000) mention that estimates based on yearly cross-section data are usually unstable. Our results indicate that the degree of competition is in a state of flux in the securities industry; thus, following Tsutsui and Kamesaka (2005) we pool our data and estimate the model for three periods between 1998 and 2006. Period 1 is from 1998 to 2000, when the global stock market underwent the Asian financial crisis shock and most countries rebuilt their stock markets and financial environments. Period 2 is from 2001 to 2003, when the government pushed financial reform to solve the problems of financial institutions burdened by a large amount of non-performing loans. Finally, period 3 is from 2004 to 2006, when the government advanced a second financial reform target to increase the performance of financial institutions. From Table 6, the H-values for the three periods are 0.4033, 0.2006 and 0.6518 , respectively. The null hypothesis $\mathrm{H}=1$ was both rejected and significant in the three periods. This implies that although the securities industry was not in perfect competition, we are still unable to reject the possibility of monopoly or variations of oligopoly for securities firms in period 1 (1998-2000) or in period 2(2001-2003). The null hypotheses $\mathrm{H}=0$ and $\mathrm{H}=1$ were rejected in period 3, indicating that the securities firms were in monopolist competition. Is there an improvement in the degree of competition faced by securities firms after 2001? To further analyse this result, we will use a more detailed model to confirm this result in the next section.

\footnotetext{
7 If the $\mathrm{H}$-statistic equals one, $\mathrm{H}=1$, the firms operate in perfect competition or monopoly in a perfectly contestable market (Gelos and Roldos, 2002).

${ }^{8}$ For instance, Coccorese (1998) has shown that the banking market is in monopolistic competition in Italy; Matthews, Murinde and Zhao (2007) found that competition in British banking is most accurately characterised by the theoretical model of monopolistic competition.
} 


\begin{tabular}{|c|c|c|c|c|c|c|c|c|c|c|}
\hline & 1998 & 1999 & 2000 & 2001 & 2002 & 2003 & 2004 & 2005 & 2006 & 1998-06 \\
\hline $\ln w$ & $\begin{array}{l}0.1185 \\
(1.672)\end{array}$ & $\begin{array}{l}0.0744 \\
(1.973)\end{array}$ & $\begin{array}{l}0.0193 \\
(0.4613)\end{array}$ & $\begin{array}{l}0.0236 \\
(0.5354) \\
\end{array}$ & $\begin{array}{l}0.0264 \\
(0.4905) \\
\end{array}$ & $\begin{array}{l}0.0591 \\
(1.653)\end{array}$ & $\begin{array}{l}0.0552 \\
(1.368)\end{array}$ & $\begin{array}{l}-0.0039 \\
(-0.148)\end{array}$ & $\begin{array}{l}-0.0119 \\
(-0.4459)\end{array}$ & $\begin{array}{l}0.0244 \\
(2.258)\end{array}$ \\
\hline $\ln k$ & $\begin{array}{l}0.0212 \\
(1.006)\end{array}$ & $\begin{array}{l}0.0149 \\
(1.169)\end{array}$ & $\begin{array}{l}-0.0108 \\
(-0.4664)\end{array}$ & $\begin{array}{l}0.0135 \\
(0.9274) \\
\end{array}$ & $\begin{array}{l}-0.0021 \\
(-0.1149)\end{array}$ & $\begin{array}{c}-0.0309 \\
(-1.255)\end{array}$ & $\begin{array}{l}-0.0066 \\
(-0.3637)\end{array}$ & $\begin{array}{l}-0.0066 \\
(-0.5099)\end{array}$ & $\begin{array}{l}-0.0054 \\
(-0.5306)\end{array}$ & $\begin{array}{l}-0.0002 \\
(-0.049)\end{array}$ \\
\hline $\ln r$ & $\begin{array}{l}-0.0129 \\
(-0.6652) \\
\end{array}$ & $\begin{array}{l}0.0114 \\
(0.6431) \\
\end{array}$ & $\begin{array}{l}-0.0397 \\
(-1.9) \\
\end{array}$ & $\begin{array}{c}-0.0276 \\
(-2.427) \\
\end{array}$ & $\begin{array}{l}-0.0099 \\
(-0.9431) \\
\end{array}$ & $\begin{array}{l}-0.0049 \\
(-0.3082) \\
\end{array}$ & $\begin{array}{l}-0.0304 \\
(-1.528) \\
\end{array}$ & $\begin{array}{l}0.0118 \\
(1.069) \\
\end{array}$ & $\begin{array}{c}-0.0048 \\
(-0.552) \\
\end{array}$ & $\begin{array}{l}-0.0038 \\
(-0.9382) \\
\end{array}$ \\
\hline BROKE & $\begin{array}{l}-0.1854 \\
(-0.4872)\end{array}$ & $\begin{array}{l}0.5905 \\
(1.569) \\
\end{array}$ & $\begin{array}{l}0.1161 \\
(0.3184) \\
\end{array}$ & $\begin{array}{l}0.1985 \\
(0.3587) \\
\end{array}$ & $\begin{array}{l}0.4597 \\
(1.267) \\
\end{array}$ & $\begin{array}{l}1.3806 \\
(2.666) \\
\end{array}$ & $\begin{array}{l}0.9472 \\
(2.199) \\
\end{array}$ & $\begin{array}{l}0.6372 \\
(1.279) \\
\end{array}$ & $\begin{array}{l}0.29 \\
(0.8819) \\
\end{array}$ & $\begin{array}{l}0.5611 \\
(6.545) \\
\end{array}$ \\
\hline UWRIT & $\begin{array}{l}-6.195 \\
(-1.382)\end{array}$ & $\begin{array}{l}-0.2782 \\
(-0.0934)\end{array}$ & $\begin{array}{l}2.014 \\
(0.5203)\end{array}$ & $\begin{array}{l}5.7585 \\
(1.891) \\
\end{array}$ & $\begin{array}{l}4.7594 \\
(1.503)\end{array}$ & $\begin{array}{l}-2.7541 \\
(-0.7035)\end{array}$ & $\begin{array}{l}2.1095 \\
(0.6131)\end{array}$ & $\begin{array}{l}1.1693 \\
(0.4354)\end{array}$ & $\begin{array}{l}4.5495 \\
(1.256)\end{array}$ & $\begin{array}{l}1.847 \\
(1.976)\end{array}$ \\
\hline$D E A L$ & $\begin{array}{l}1.7291 \\
(2.728)\end{array}$ & $\begin{array}{l}0.9412 \\
(3.793)\end{array}$ & $\begin{array}{l}0.1884 \\
(0.6264)\end{array}$ & $\begin{array}{l}0.9497 \\
(3.209)\end{array}$ & $\begin{array}{l}0.3029 \\
(0.6328)\end{array}$ & $\begin{array}{l}1.2479 \\
(2.768)\end{array}$ & $\begin{array}{l}0.8488 \\
(1.84)\end{array}$ & $\begin{array}{l}0.7036 \\
(2.068)\end{array}$ & $\begin{array}{l}0.765 \\
(2.195)\end{array}$ & $\begin{array}{l}0.8133 \\
(7.914)\end{array}$ \\
\hline$(\ln w)^{2}$ & $\begin{array}{l}0.1524 \\
(0.6791) \\
\end{array}$ & $\begin{array}{l}-0.0645 \\
(-0.3269) \\
\end{array}$ & $\begin{array}{l}-0.108 \\
(-0.6963)\end{array}$ & $\begin{array}{l}-0.0779 \\
(-0.8962)\end{array}$ & $\begin{array}{l}-0.1767 \\
(-1.59) \\
\end{array}$ & $\begin{array}{l}0.0708 \\
(0.4372) \\
\end{array}$ & $\begin{array}{l}-0.1142 \\
(-0.7137)\end{array}$ & $\begin{array}{l}-0.0549 \\
(-0.6311)\end{array}$ & $\begin{array}{l}0.1037 \\
(2.195) \\
\end{array}$ & $\begin{array}{l}-0.0266 \\
(-0.8118) \\
\end{array}$ \\
\hline$(\ln k)^{2}$ & $\begin{array}{l}-0.04 \\
(-1.478)\end{array}$ & $\begin{array}{l}-0.0128 \\
(-0.7163)\end{array}$ & $\begin{array}{l}-0.0353 \\
(-0.5661) \\
\end{array}$ & $\begin{array}{l}0.038 \\
(0.9241) \\
\end{array}$ & $\begin{array}{l}-0.0836 \\
(-2.59) \\
\end{array}$ & $\begin{array}{l}-0.0129 \\
(-0.2428)\end{array}$ & $\begin{array}{l}-0.0446 \\
(-1.775) \\
\end{array}$ & $\begin{array}{l}-0.0288 \\
(-2.004) \\
\end{array}$ & $\begin{array}{l}-0.0185 \\
(-1.554) \\
\end{array}$ & $\begin{array}{l}-0.0238 \\
(-3.82) \\
\end{array}$ \\
\hline$(\ln r)^{2}$ & $\begin{array}{l}-0.0084 \\
(-0.7174)\end{array}$ & $\begin{array}{l}0.0075 \\
(0.5946)\end{array}$ & $\begin{array}{l}-0.0184 \\
(-0.6409)\end{array}$ & $\begin{array}{l}-0.0137 \\
(-2.12) \\
\end{array}$ & $\begin{array}{l}0.0044 \\
(0.5738)\end{array}$ & $\begin{array}{l}-0.0158 \\
(-0.6764)\end{array}$ & $\begin{array}{l}-0.0282 \\
(-1.188)\end{array}$ & $\begin{array}{l}0.0278 \\
(1.216)\end{array}$ & $\begin{array}{l}0.0042 \\
(0.607)\end{array}$ & $\begin{array}{l}0.0002 \\
(0.0601)\end{array}$ \\
\hline$R^{2}$ & 0.815 & 0.8159 & 0.5919 & 0.861 & 0.8718 & 0.635 & 0.8699 & 0.7 & 0.7038 & 0.5201 \\
\hline H-statistic & 0.1266 & 0.1008 & -0.0312 & 0.0095 & 0.0144 & 0.0232 & 0.018 & $0.1341 \mathrm{E}-2$ & -0.0223 & 0.0203 \\
\hline \multirow[t]{2}{*}{$\mathrm{H}=\mathrm{O}$} & 2.754 & $4.8407^{*}$ & 0.3123 & 0.0315 & 0.0505 & 0.2458 & 0.1845 & 0.0013 & 0.3779 & 2.1907 \\
\hline & $\mathrm{E}$ & DISE & $\mathrm{E}$ & $\mathrm{E}$ & $\mathrm{E}$ & $\mathrm{E}$ & $\mathrm{E}$ & $\mathrm{E}$ & $\mathrm{E}$ & $\mathrm{E}$ \\
\hline
\end{tabular}

Notes: the dependent variable is ROA, w indicates the wage rate, $k$ indicates the price of capital equipment, and $\mathrm{r}$ indicates the cost of funding. BROKE indicate the brokerage fee divide by assets, UWRI indicates the underwrite fee divide by assets and DEAL indicates the securities firms income (lose) from equity dealing divide by asset. The null hypothesise $\mathrm{H}=0$ is to test market whether in the long-ru equilibrium, and used the F-test to test its, $\mathrm{E}$ indicates the sample in long-run equilibrium. DISE indicates the sample in disequilibrium. ${ }^{*} \alpha=0.1$ significant at the $10 \%$ level, $* * \alpha=0.05$ significant at the $5 \%$ level, $* * * \alpha=0.01$ significant at the $1 \%$ level. 
Asian Economic and Financial Review, 2018, 8(4): 499-514.

Table-5. Results of estimate the degree of competition

\begin{tabular}{|c|c|c|c|c|c|c|c|c|c|c|}
\hline & 1998 & 1999 & 2000 & 2001 & 202 & 2003 & 2004 & 2005 & 2006 & 1998-06 \\
\hline $\ln w$ & $\begin{array}{l}-0.4738 \\
(-0.536) \\
\end{array}$ & $\begin{array}{l}-0.1128 \\
(-0.4344) \\
\end{array}$ & $\begin{array}{l}0.2409 \\
(0.8822) \\
\end{array}$ & $\begin{array}{l}-0.3419 \\
(-1.439)\end{array}$ & $\begin{array}{l}0.7232 \\
(1.59)\end{array}$ & $\begin{array}{l}0.259 \\
(0.8337)\end{array}$ & $\begin{array}{l}0.7399 \\
(1.955)^{*}\end{array}$ & $\begin{array}{l}0.3639 \\
(1.735)^{*}\end{array}$ & $\begin{array}{l}0.3278 \\
(1.293)\end{array}$ & $\begin{array}{l}0.2668 \\
(2.815)^{* * *}\end{array}$ \\
\hline $\ln k$ & $\begin{array}{l}-0.3007 \\
(-1.144) \\
\end{array}$ & \begin{tabular}{|l|}
0.0464 \\
$(0.528)$ \\
\end{tabular} & $\begin{array}{l}-0.0266 \\
(-0.1761) \\
\end{array}$ & $\begin{array}{l}-0.0109 \\
(-0.1389) \\
\end{array}$ & $\begin{array}{l}-0.0554 \\
(-0.3603)\end{array}$ & $\begin{array}{l}0.0936 \\
(0.4362) \\
\end{array}$ & $\begin{array}{l}0.0649 \\
(0.3766) \\
\end{array}$ & $\begin{array}{l}0.2046 \\
(2.015)^{* *}\end{array}$ & $\begin{array}{l}0.1771 \\
(1.818)^{*}\end{array}$ & $\begin{array}{l}0.0578 \\
(1.461) \\
\end{array}$ \\
\hline $\ln r$ & \begin{tabular}{|l|}
0.3248 \\
$(1.333)$ \\
\end{tabular} & \begin{tabular}{|l|}
0.2037 \\
$(1.662)$ \\
\end{tabular} & $\begin{array}{l}-0.0131 \\
(-0.0964)\end{array}$ & $\begin{array}{l}0.1621 \\
(2.642)^{* * *}\end{array}$ & $\begin{array}{l}0.0566 \\
(0.6357) \\
\end{array}$ & $\begin{array}{l}-0.131 \\
(-0.9304) \\
\end{array}$ & $\begin{array}{l}-0.2411 \\
(-1.29) \\
\end{array}$ & $\begin{array}{l}0.1944 \\
(2.225)^{* *}\end{array}$ & $\begin{array}{l}0.0274 \\
(0.3314) \\
\end{array}$ & $\begin{array}{l}0.1304 \\
(3.606)^{* * * *}\end{array}$ \\
\hline BROKE & $\begin{array}{l}21.287 \\
(4.75)^{* * *}\end{array}$ & $\begin{array}{l}9.4094 \\
(3.633)^{* * *}\end{array}$ & $\begin{array}{l}8.4501 \\
(3.563)^{* * * *}\end{array}$ & $\begin{array}{l}10.893 \\
(3.657)^{* * *}\end{array}$ & $\begin{array}{l}15.949 \\
(5.23)^{* * * *}\end{array}$ & $\begin{array}{l}15.466 \\
(3.437)^{* * * *}\end{array}$ & $\begin{array}{l}13.086 \\
(3.24)^{* * * *}\end{array}$ & $\begin{array}{l}21.911 \\
(5.601)^{* * *}\end{array}$ & $\begin{array}{l}6.8727 \\
(2.216)^{* *}\end{array}$ & $\begin{array}{l}13.331 \\
(17.78)^{* * *}\end{array}$ \\
\hline UWRIT & $\begin{array}{l}100.82 \\
(55.95)^{* * * *}\end{array}$ & $\begin{array}{l}35.315 \\
(1.723)^{*}\end{array}$ & $\begin{array}{l}9.6136 \\
(0.3817)\end{array}$ & $\begin{array}{l}18.576 \\
(1.134)\end{array}$ & $\begin{array}{l}21.086 \\
(0.7924)\end{array}$ & $\begin{array}{l}69.449 \\
(2.041)^{* * *}\end{array}$ & $\begin{array}{l}-19.534 \\
(-0.6054)\end{array}$ & $\begin{array}{l}5.8785 \\
(0.2787)\end{array}$ & $\begin{array}{l}61.087 \\
(1.789)^{*}\end{array}$ & $\begin{array}{l}16.664 \\
(2.039)^{* *}\end{array}$ \\
\hline$D E A L$ & $\begin{array}{l}-0.495 \\
(-0.0625) \\
\end{array}$ & \begin{tabular}{|l|}
6.8809 \\
$(4.03)^{* * * *}$ \\
\end{tabular} & $\begin{array}{l}0.4828 \\
(0.2468) \\
\end{array}$ & $\begin{array}{l}0.0399 \\
(0.0251) \\
\end{array}$ & $\begin{array}{l}6.12 \\
(1.521) \\
\end{array}$ & $\begin{array}{l}3.7121 \\
(0.9475) \\
\end{array}$ & $\begin{array}{l}6.649 \\
(1.536) \\
\end{array}$ & $\begin{array}{l}9.6994 \\
(3.631)^{* * * *}\end{array}$ & $\begin{array}{l}7.017 \\
(2.136)^{* *}\end{array}$ & $\begin{array}{l}3.4646 \\
(3.856) * * *\end{array}$ \\
\hline$(\ln w)^{2}$ & $\begin{array}{l}-3.3134 \\
(-1.183) \\
\end{array}$ & \begin{tabular}{|l|}
2.3971 \\
$(1.763)^{*}$
\end{tabular} & $\begin{array}{l}-0.1007 \\
(-0.0998)\end{array}$ & $\begin{array}{l}1.5526 \\
(3.316)^{* * *}\end{array}$ & $\begin{array}{l}-1.6157 \\
(-1.729)^{*}\end{array}$ & $\begin{array}{l}1.1792 \\
(0.8377)\end{array}$ & $\begin{array}{l}-2.2332 \\
(-1.488)\end{array}$ & $\begin{array}{l}-0.2382 \\
(-0.3485)\end{array}$ & $\begin{array}{l}0.8547 \\
(1.014)\end{array}$ & $\begin{array}{l}0.2328 \\
(0.8096)\end{array}$ \\
\hline$(\ln k)^{2}$ & $\begin{array}{l}0.0408 \\
(0.1208)\end{array}$ & $\begin{array}{l}-0.0623 \\
(-0.5052) \\
\end{array}$ & $\begin{array}{l}-0.2828 \\
(-0.6851)\end{array}$ & $\begin{array}{l}-0.552 \\
(-2.495)^{* *}\end{array}$ & $\begin{array}{l}-0.3192 \\
(-1.176)\end{array}$ & $\begin{array}{l}0.5686 \\
(1.23)\end{array}$ & $\begin{array}{l}0.2866 \\
(1.216)\end{array}$ & $\begin{array}{l}0.0943 \\
(0.8337)\end{array}$ & $\begin{array}{l}0.051 \\
(0.4539)\end{array}$ & $\begin{array}{l}-0.1007 \\
(-1.85)^{*}\end{array}$ \\
\hline$(\ln r)^{2}$ & $\begin{array}{l}0.1138 \\
(0.7773) \\
\end{array}$ & \begin{tabular}{|l|}
0.1587 \\
$(1.817)$ \\
\end{tabular} & $\begin{array}{l}0.0642 \\
(0.3428)\end{array}$ & $\begin{array}{l}0.0933 \\
(2.677)^{* * *}\end{array}$ & $\begin{array}{l}0.0359 \\
(0.5552)\end{array}$ & $\begin{array}{l}-0.2196 \\
(-1.083)\end{array}$ & $\begin{array}{l}-0.3302 \\
(-1.481)\end{array}$ & $\begin{array}{l}0.0165 \\
(0.0918)\end{array}$ & $\begin{array}{l}0.0126 \\
(0.1916)\end{array}$ & $\begin{array}{l}0.0762 \\
(2.833)^{* * *}\end{array}$ \\
\hline$R^{2}$ & 0.7643 & 0.7802 & 0.7343 & 0.9273 & 0.8737 & 0.7738 & 0.6946 & 0.923 & 0.8121 & 0.7032 \\
\hline H-statistic & -0.4498 & 0.1374 & 0.2011 & -0.1908 & 0.7244 & 0.2218 & 0.5638 & 0.7629 & 0.5324 & 0.4551 \\
\hline $\mathrm{H}=\mathrm{O}$ & 0.2235 & 0.1899 & 0.3053 & 0.4362 & 1.8199 & 0.298 & 2.039 & $6.8429 * *$ & 2.4179 & $14.3028^{* * * *}$ \\
\hline \multirow[t]{2}{*}{$\mathrm{H}=1$} & 2.3174 & $7.4868^{* * *}$ & $4.8175^{*}$ & $16.9924 * * *$ & 2.2634 & $3.6662^{*}$ & 1.22 & 0.6602 & 1.8646 & $20.4994^{* * * *}$ \\
\hline & $\mathrm{M}$ & $\mathrm{M}$ & $\mathrm{M}$ & $\mathrm{M}$ & $\mathrm{MC}$ & $\mathrm{M}$ & $\mathrm{MC}$ & $\mathrm{PC}$ & $\mathrm{MC}$ & $\mathrm{MC}$ \\
\hline
\end{tabular}

dependent variable is log total revenue divide by total asset (TRTA), all independent variables definition see Table 4 . The column $\mathrm{H}=0$ and $\mathrm{H}=1$ are present $\mathrm{F}$-value for null hypotheses. $\mathrm{M}$ ${ }^{*} * * \alpha=0.01$ significant at the $1 \%$ level. 
Asian Economic and Financial Review, 2018, 8(4): 499-514

Table-6. Results of three stages of degree of competition

\begin{tabular}{|c|c|c|c|}
\hline & Period 1 & Period 2 & Period 3 \\
\hline & $1998-2000$ & $2001-2003$ & 2004-2006 \\
\hline $\ln w$ & $\begin{array}{l}0.2904 \\
(1.399)\end{array}$ & $\begin{array}{l}0.0812 \\
\left(\begin{array}{ll}0.44 & 9\end{array}\right)\end{array}$ & $\begin{array}{l}0.398 \\
(2.695)\end{array}$ \\
\hline $\ln k$ & $\begin{array}{l}-0.0311 \\
(-0.3355)\end{array}$ & $\begin{array}{l}-0.0062 \\
(-0.0705)\end{array}$ & $\begin{array}{l}0.165 \\
(2.398)\end{array}$ \\
\hline $\ln r$ & $\begin{array}{l}0.1439 \\
(1.471)\end{array}$ & $\begin{array}{l}0.1255 \\
(2.544)\end{array}$ & $\begin{array}{l}0.0888 \\
(1.498)\end{array}$ \\
\hline$B R O K E$ & $\begin{array}{l}12.584 \\
(7.175)\end{array}$ & $\begin{array}{c}14.291 \\
(7.625)\end{array}$ & $\begin{array}{l}13.754 \\
(8.206)\end{array}$ \\
\hline UWRIT & $\begin{array}{l}16.126 \\
(0.9812)\end{array}$ & $\begin{array}{l}10.344 \\
(0.7171)\end{array}$ & $\begin{array}{l}9.2913 \\
(0.5864)\end{array}$ \\
\hline$D E A L$ & $\begin{array}{l}1.9717 \\
(1.125) \\
\end{array}$ & $\begin{array}{l}4.0404 \\
(2.68)\end{array}$ & $\begin{array}{l}6.353 \\
(3.268)\end{array}$ \\
\hline$(\ln w)^{2}$ & $\begin{array}{l}0.5571 \\
(0.6318)\end{array}$ & $\begin{array}{l}0.6642 \\
(1.689)\end{array}$ & $\begin{array}{l}-0.5355 \\
(-0.9562)\end{array}$ \\
\hline$(\ln k)^{2}$ & $\begin{array}{l}-0.0475 \\
(-0.3366)\end{array}$ & $\begin{array}{l}-0.2943 \\
(-1.826)\end{array}$ & $\begin{array}{l}0.0364 \\
(0.452)\end{array}$ \\
\hline$(\ln r)^{2}$ & $\begin{array}{l}0.1101 \\
(1.528)\end{array}$ & $\begin{array}{l}0.0715 \\
(2.106)\end{array}$ & $\begin{array}{l}0.0172 \\
(0.2935)\end{array}$ \\
\hline$R^{2}$ & 0.5581 & 0.6714 & 0.7011 \\
\hline H-statistic & 0.4033 & 0.2006 & 0.6518 \\
\hline $\mathrm{H}=\mathrm{O}$ & 2.3492 & 0.7173 & $10.677^{\text {***** }}$ \\
\hline \multirow[t]{2}{*}{$\mathrm{H}=1$} & $5.1442^{* * *}$ & $11.3879^{* * * *}$ & $3.0457 *$ \\
\hline & $\mathrm{M}$ & $\mathrm{M}$ & $\mathrm{MC}$ \\
\hline
\end{tabular}

Notes: the dependent variable is total revenue divide by total asset (TRTA), ${ }^{*} \alpha=0.1$ significant at the $10 \%$ level, ${ }^{*} * \alpha=0.05$ significant at the $5 \%$ level, $* * * \alpha=0.01$ significant at the $1 \%$ level.

\subsection{Results of Dynamic Degree of Competition: A Dummy Model}

In this section, we focus on whether the degree of competition has changed across break points separating years. Following Gelos and Roldos (2004) this test is implemented by dividing the period 1998 to 2006 into two sub-periods and interacting the input price variables with a dummy variable that takes the value one in the second sub-period. If the interaction term yields a significant estimate, it indicates a structural break in the statistical relationship between input price and the revenues variable. We use a time dummy model to test for a structural change in the degree of competition; this model may help us to confirm whether the competitive condition has improved. We choose 2001 as the year marking the structural break. Since 2001, the government implemented its first financial reform, mainly to improve the financial strength of banks; in addition, there have been many important financial policy developments regarding the future operations of financial institutions, i.e., a merger act, a financial holding company act, and a financial institution restructuring act. We also choose 2004 as the year marking the structural break, because the former result shows a higher degree of competition for period 3 than for prior periods. The empirical function of testing for structural change is as below:

$$
\begin{gathered}
\ln \operatorname{TRTA}_{i t}=b_{0}+b_{1} \ln w_{i t} * D_{0}+b_{2} \ln k_{i t} * D_{0}+b_{3} \ln r_{i t}^{*} D_{0}+b_{4} \ln w_{i t} * D_{1}+b_{5} \ln k_{i t} * D_{1} \\
+b_{6} \ln r_{i t} * D_{1}+b_{7} B R O K E_{i t}+b_{8} U W R I T_{i t}+b_{9} D E A L_{i t}+u_{i t} \\
H_{\text {early }}=b_{1}+b_{2}+b_{3} ; H_{\text {late }}=b_{4}+b_{5}+b_{6},
\end{gathered}
$$

where $D_{0}$ is a dummy variable, which equals one if the study period is before 2001 (2004), and zero otherwise. $D_{1}$ is a dummy variable, which equals one if the study period is after 2002, and zero otherwise. The null hypothesis $H_{\text {late }}-H_{\text {early }}=0$, if the null hypothesis is not rejected, indicating that there has been no change of competitive condition. 
As can be seen Table 7 , the results do reject null hypothesis $H_{R O A}=0$ with Models A and B, indicating that the samples are in long-run equilibrium. The value of $H_{\text {late }}-H_{\text {early }}$ is 1.2262 with Model A the value of $H_{\text {late }}-H_{\text {early }}$ is 0.5219 with Model B, and the F-value is 0.5219 and $0.7736 \mathrm{E}$-3,respectivity. Thus, we are unable to reject the null hypothesis of no change in the H-statistic. Unfortunately, this implies that the securities firms' competitive condition is not being improved and that the government's adoption a series of financial reform policies do not significantly affect industry competition. Tsutsui and Kamesaka (2005) find that deregulation of brokerage fees in the late 1990s did have a strong impact on competition and that brokerage commission rates continue to be very competitive, implying that the securities firms still face a fragmented brokerage market and heightened price competition in the online trading realm. ${ }^{9}$ Thus, the notion that the deregulation of brokerage fees might have been improving the competitive condition is considered. However, it is likely that, as Tsutsui and Kamesaka (2005) have stated, policy measures do not always have a strong impact on competition. The financial reform policies are not a strong influence on competition, but the H-statistic increases from 0.2621 to 1.4883 with model A, and the model B has a similar result (from 0.2762 to 0.7981 ); the results thus imply that the degree of competition might be improved. However, we do not have strong evidence for this scenario.

Table-7. Results of change of degrees of competition

\begin{tabular}{|c|c|c|}
\hline & Dependent variable $=\mathrm{ROA}$ & \\
\hline & Model A & Model B \\
\hline $\ln w^{*} D_{0}$ & $\begin{array}{l}0.2753 \\
(2.159)^{* * *}\end{array}$ & $\begin{array}{l}0.2603 \\
(2.263)^{* * *}\end{array}$ \\
\hline $\ln k * D_{0}$ & $\begin{array}{l}-0.0538 \\
(-0.9443)\end{array}$ & $\begin{array}{l}-0.0216 \\
(-0.4457)\end{array}$ \\
\hline $\ln r * D_{0}$ & $\begin{array}{l}0.0405 \\
(1.168)\end{array}$ & $\begin{array}{l}0.0375 \\
(1.283)\end{array}$ \\
\hline $\ln w^{*} D_{1}$ & $\begin{array}{l}-1.9168 \\
(-2.254) * *\end{array}$ & $\begin{array}{l}-1.752 \\
(-1.628)\end{array}$ \\
\hline $\ln k * D_{1}$ & $\begin{array}{l}-0.4973 \\
(-0.0331)\end{array}$ & $\begin{array}{l}-1.9816 \\
(-0.0998)\end{array}$ \\
\hline $\ln r * D_{1}$ & $\begin{array}{l}3.9025 \\
(2.211)^{* * *}\end{array}$ & $\begin{array}{l}4.5317 \\
(2.185)^{* *}\end{array}$ \\
\hline BROKE & $\begin{array}{l}12.781 \\
(16.09)^{* * * *}\end{array}$ & $\begin{array}{l}12.977 \\
(16.3)^{* * * *}\end{array}$ \\
\hline$U W R I T$ & $\begin{array}{l}24.266 \\
(2.417)^{* * *}\end{array}$ & $\begin{array}{l}24.099 \\
(2.63)^{* *}\end{array}$ \\
\hline$D E A L$ & $\begin{array}{l}1.8366 \\
(1.714)^{*}\end{array}$ & $\begin{array}{l}2.4903 \\
(2.512)^{* * *}\end{array}$ \\
\hline$R^{2}$ & 0.6965 & 0.686 \\
\hline$H_{\text {early }}$ & 0.2621 & 0.2762 \\
\hline$H_{\text {late }}$ & 1.4883 & 0.7981 \\
\hline \multirow[t]{2}{*}{$\mathrm{H}=\mathrm{O}$} & 0.0075 & $0.7736 \mathrm{E}-3$ \\
\hline & No Change & No Change \\
\hline
\end{tabular}

Notes: Model A break point at 2004, Model B break point at 2001, using the dependent variable is ROA to test whether the sample in the longrun equilibrium, the results show not reject null hypothesis $H_{R O A}=0$ in two models, the F-value are 0.8843 and 0.7826 ,respectivity. Thus, our estimated samples are in long-run equilibrium ${ }^{*} \alpha=0.1$ significant at the $10 \%$ level, ${ }^{*} \alpha=0.05$ significant at the $5 \%$ level, ${ }^{*} * * \alpha=0.01$ significant at the $1 \%$ level.

${ }_{9}$ The government has limited the brokerage commission rates from zero to $0.1425 \%$, but securities firms often will give a discount rate that ranges from $30 \%$ to $35 \%$ for customers. 


\section{CONCLUDING REMARKS}

The purpose of this study was to investigate securities firms' market structure and contestability in Taiwan. We find that the SCP and ESX are not supported and that the RMP and ESS are supported. The results show that the RMP and ESS hypotheses are supported, but, compared with each coefficient in regression (1), this suggests that the RMP hypothesis has stronger supporting evidence than does the ESS hypothesis. This study finds that market share may not have a significant impact on firms' efficiency but may significantly impact profitability. Under the lower degree of competition, firms have a higher profit despite not achieving high efficiency because they are facing fewer competitive rivals within their markets. Even through many changes and financial reforms were made for securities firms in Taiwan during the period of analysis, competitive conditions did not change significantly over the period from 1998-2006. The securities industry is still in a lower level of competition.

This is the first study to integrate structural and non-structural approaches to evaluate competitive conditions in securities firms. We find that results of structural and non-structural approaches are compatible. The results show that market share may not significantly impact firms' efficiency but does influence profitability. This implies that their excessive rent as a result of market structure signals an imperfect market. The evaluation of competitive conditions showed that securities firms were not in perfect competition, so excessive rent may exist in securities firms, offering these firms little incentive to improve their efficiency.

Funding: The author is grateful for Financial support from Samming University (Grant No.16YGo9S) enabling this research to be completed.

Competing Interests: The authors declare that they have no competing interests.

Contributors/Acknowledgement: I would like to thank, without implicating, Dr. Fung-Shyung Shiau and anonymous referee for their insightful and painstaking comments on an earlier draft which greatly improved the clarity and exposition of the paper. I am responsible for all remaining errors.

\section{REFERENCES}

Al-Muharrami, S., K. Matthews and Y. Khabari, 2006. Market structure and competitive conditions in the Arab GCC banking system. Journal of Banking and Finance, 30(12): 3487-3501. View at Google Scholar | View at Publisher

Berger, A.N., 1995. The profit structure relationship in banking-tests of market-power and efficient-structure hypotheses. Journal of Money, Credit and Banking, 27(2): 404-431. View at Google Scholar | View at Publisher

Berger, A.N. and T.H. Hannan, 1993. Using efficiency measures to distinguish among alternative explanations of the structureperformance relationship in banking. Federal Reserve Board Working Paper.

Berger, A.N. and T.H. Hannan, 1998. The efficiency cost of market power in the banking industry: A test of the "quiet life" and related hypotheses. Review of Economics and Statistics, 80(3): 454-465. View at Google Scholar $\mid$ View at Publisher

Bikker, J.A. and K. Haaf, 2002. Competition, concentration and their relationship: An empirical analysis of the banking industry. Journal of Banking and Finance, 26(11): 2191-2214. View at Google Scholar |View at Publisher

Choi, B.P. and M.A. Weiss, 2005. An empirical investigation of market structure, efficiency, and performance in propertyliability insurance. Journal of Risk and Insurance, 72(4): 635-673. View at Google Scholar | View at Publisher

Christensen, L.R., D.W. Jorgensen and L.J. Lau, 1973. Transcendental logarithmic production frontiers. Review of Economics and Statistics, 55(1): 28-45. View at Google Scholar | View at Publisher

Chu, W., C.N. Chen and C.H. Wang, 2008. The market share-profitability relationships in the securities industry. Service Industrial Journal, 28(6): 813-826. View at Google Scholar | View at Publisher

Coccorese, P., 1998. Assessing the competitive conditions in the Italian banking system: Some empirical evidence. BNL Quarterly Review, 51(205): 173-191.

Coccorese, P., 2009. Market power in local banking monopolies. Journal of Banking and Finance, 33(7): 1196-12 10. View at Google Scholar $\mid$ View at Publisher

De Bandt, O. and E.P. Davis, 2000. Competition, contestability and market structure in European banking sectors on the eve of EMU. Journal of Banking and Finance, 24(6): 1045-1066. View at Google Scholar | View at Publisher 
Fukuyama, H. and W.L. Weber, 1999. The efficiency and productivity of Japanese securities firms, 1988-93. Japan and the World Economy, 11(1): 115-133. View at Google Scholar | View at Publisher

Gelos, G. and J. Roldos, 2002. Consolidation and market structure in emerging banking systems. IMF Working Paper, No. WP/02/186.

Gelos, G. and J. Roldos, 2004. Consolidation and market structure in emerging banking systems. Emerging Market Review, 5(1): 39-59. View at Google Scholar | View at Publisher

Goldberg, L.G. and A. Rai, 1996. The structure - performance relationship for European banking. Journal of Banking and Finance, 20(4): 745-771. View at Google Scholar | View at Publisher

Hahn, F.R., 2008. Testing for profitability and contestability in banking: Evidence from Austria. International Review of Applied Economics, 22(5): 639-653. View at Google Scholar |View at Publisher

Hicks, J., 1935. Annual survey of economics theory: The theory of monopoly. Econometrica, 3(1): 1-20. View at Google Scholar $\mid$ View at Publisher

Liao, C.S., 2010. Determinants of X-efficiency in securities industry: The case of Taiwan. Empirical Economics Letters, 9(1): 713.

Matthews, K., V. Murinde and T. Zhao, 2007. Competitive conditions among the major British banks. Journal of Banking and Finance, 31(7): 2025-2042. View at Google Scholar | View at Publisher

Molyneux, P., D.M. Lloyd-Williams and J. Thornton, 1994. Competitive conditions in European banking. Journal of Banking and Finance, 18(3): 445-459. View at Google Scholar $\mid$ View at Publisher

Molyneux, P., J. Thornton and D.M. Lloyd-Williams, 1996. Competition and market contestability in Japanese commercial banking. Journal of Economics and Business, 48(1): 33-45. View at Google Scholar $\mid$ View at Publisher

Panzar, J.C. and J.N. Rosse, 1987. Testing for “monopoly” equilibrium. Journal of Industrial Economics, 35(4): 443-456. View at Google Scholar | View at Publisher

Park, K.H. and W.L. Weber, 2006. Profitability of Korean banks: Test of market structure versus efficient structure. Journal of Economics and Business, 58(3): 222-239. View at Google Scholar | View at Publisher

Samad, A., 2008. Market structure, conduct and performance: Evidence from the Bangladesh banking industry. Journal of Asian Economics, 19(2): 181-193. View at Google Scholar | View at Publisher

Shaffer, S., 1982. A-non-structural test for competition in financial market. In: Bank Structure and Competition Conference Proceedings, Federal Reserve Bank of Chicago, Chicago.

Tsutsui, Y. and A. Kamesaka, 2005. Degree of competition in the Japanese securities industry. Journal of Economics and Business, 57(4): 360-374. View at Google Scholar | View at Publisher

Wang, K.L., Y.T. Tseng and C.C. Weng, 2003. A study of production efficiency of integrated securities firms in Taiwan. Applied Financial Economics, 13(3): 159-167. View at Google Scholar | View at Publisher

Yu, P., 2003. Competitive issues in the Taiwanese banking industry: Mergers and universal banks. Developing Economies, 41(3): 309-339. View at Google Scholar | View at Publisher

Yuan, Y., 2006. The state of competition of the Chinese banking industry. Journal of Asian Economics, 17(3): 519-534. View at Google Scholar

Zhang, W., S. Zhang and X. Luo, 2006. Technological progress, inefficiency, and productivity growth in the US securities industry, 1980-2000. Journal of Business Research, 59(5): 589-594. View at Google Scholar $\mid$ View at Publisher

Views and opinions expressed in this article are the views and opinions of the author(s), Asian Economic and Financial Review shall not be responsible or answerable for any loss, damage or liability etc. caused in relation to/arising out of the use of the content. 